\title{
Proximal aortic arch cannulation for proximal ascending aortic aneurysms
}

\author{
Bilgin Emrecan, Firat Durna, Serkan Girgin, Mohammed Alshalaldeh \\ Department of Cardiovascular Surgery, Pamukkale University, Denizli, Turkey \\ Kardiochirurgia i Torakochirurgia Polska 2014; 11 (2): 132-135
}

\begin{abstract}
Introduction: Different arterial inflow sites have been reported to date for particularly challenging cardiac operations. The ascending aorta, femoral artery, and subclavian artery are the most commonly used sites. Although its use has been reported, the aortic arch has not gained popularity in the performance of cannulation. According to a search performed in the PubMed database, aortic arch cannulation for ascending aorta replacement has not been examined in a separate study before. In the present study, we report the treatment outcomes of patients with ascending aortic aneurysms in whom the aortic arch was cannulated for arterial inflow.

Material and methods: Twenty-seven patients with aneurysmal dilatation of the ascending aorta underwent ascending aorta replacement from April 2010 to March 2013. The mean age of the patients was 64 years. All operations were carried out by cannulating the aortic arch distally from the origin of the innominate artery.

Results: There was no mortality or cannulation-related morbidity. In 23 patients, only the supracoronary ascending aorta was replaced, whereas in 4 patients, the button modification of the Bentall procedure was performed to replace the root and the ascending aorta.

Conclusions: The technique of aortic arch cannulation distal to the origin of the innominate artery is worthy of consideration in the treatment of aneurysms limited to the ascending aorta due to its safety, simplicity, and low morbidity.

Key words: aneurysm, aorta/aortic, cardiopulmonary bypass.
\end{abstract}

\section{Introduction}

Formerly, arterial inflow sites included mainly the subclavian and femoral arteries. Currently, arterial inflow is usually provided through the cannulation of the ascending aorta. Safety, simplicity, and the lack of additional incisions constitute the advantages of this approach over the femo-

\section{Streszczenie}

Wstęp: W wypadku szczególnie wymagających operacji serca do zapewnienia napływu tętniczego stosowane są różne miejsca kaniulacji. Do najczęściej stosowanych należą aorta wstępująca, tętnica udowa i tętnica podobojczykowa. Mimo że odnotowane zostały również przypadki stosowania łuku aorty, wciąż nie jest on popularnym miejscem kaniulacji. Zgodnie z informacjami znalezionymi w bazie danych PubMed kaniulacja łuku aorty przy operacji wymiany aorty wstępującej nie była jeszcze badana w ramach odrębnego opracowania W niniejszej pracy przedstawiono wyniki leczenia pacjentów z tętniakami aorty wstępującej, u których przeprowadzono kaniulację łuku aorty celem zapewnienia napływu tętniczego. Materiat i metody: Od kwietnia 2010 r. do marca 2013 r. operację wymiany aorty wstępującej z powodu tętniaka wykonano u 27 pacjentów. Średni wiek pacjentów wynosił 64 lata. Wszystkie operacje przeprowadzone zostały przez kaniulację łuku aorty dystalnie od odejścia tętnicy bezimiennej (pnia ramienno-głowowego).

Wyniki: W badanej grupie nie stwierdzono zgonów związanych z kaniulacją. U 23 pacjentów wszczepiona została jedynie proteza nadwieńcowego odcinka aorty wstępującej, natomiast u 4 pacjentów przeprowadzono zmodyfikowaną operację metodą Bentalla (button modification) w celu wymiany pnia oraz aorty wstępującej.

Wnioski: Technika kaniulacji łuku aorty dystalnie od odejścia tętnicy bezimiennej jest warta rozważenia w przypadku leczenia tętniaków ograniczonych do aorty wstępującej ze względu na jej bezpieczeństwo, prostotę wykonania i niską chorobowość.

Słowa kluczowe: tętniak, aorta/aortalny, krążenie pozaustrojowe.

ral or iliac arteries. The cannulation site is selected based on the type of cannula to be used, the operation planned (how much of the ascending aorta must be available), and the quality of the aortic wall [1]. Some authors propose the aortic arch for cannulation as an alternative to the ascending aorta [2]. Conversely, other authors reported the use of

Address for correspondence: Assoc. Prof. Bilgin Emrecan, Gerzele mahallesi 593/1 sok No: 42, Denizli, 20040/Turkey, tel. +905054889916, e-mail: bilginemrecan@yahoo.com 
aortic arch cannulation in challenging situations, such as ascending aorta calcifications or wall abnormalities, where cannulation may complicate the procedure [3]. However, these operations were mainly aimed at preventing cerebral events. According to a search performed in the PubMed database, aortic arch cannulation for ascending aorta replacement has not been assessed in a separate study before. In the present study, we retrospectively analyzed the treatment outcomes of patients with ascending aortic aneurysms in whom the aortic arch was cannulated for arterial inflow. We also made an attempt to discuss the associated technical pitfalls and challenges.

\section{Material and methods}

From April 2010 to March 2013, a total of 27 patients underwent ascending aorta replacement for aneurysmal dilatation at our institution. The study population included 19 male and 8 female patients at a mean age of 64 years (range: 53-75 years). All operations were performed by the same surgeon. Surgical indications included either an ascending aortic aneurysm alone or other cardiac disease accompanying the aneurysmal dilatation of the ascending aorta.

All patients were operated on with the use of aortic arch cannulation for arterial inflow. In all cases, the aneurysmal dilatation was limited to the ascending aorta. Patients with aortic arch aneurysms, aortic dissection, and severe aortic arch calcification were excluded from the study. All decisions were made on the basis of computed tomographic imaging.

All operations were performed via median sternotomy. After pericardiotomy, the aortic arch was exposed by dissecting the overlying tissues. The anterior side of the aortic arch distal to the origin of the innominate artery was selected as the arterial cannulation site (Fig. 1). Two purse sutures, one of them with two pledgets on each side, were used for the cannulation. A standard curved-tip ascending aortic arterial cannula was inserted by pulling the ascending aorta downwards, either with a gauze pad or a clamp attached to the adventitia of the ascending aorta (Fig. 2).

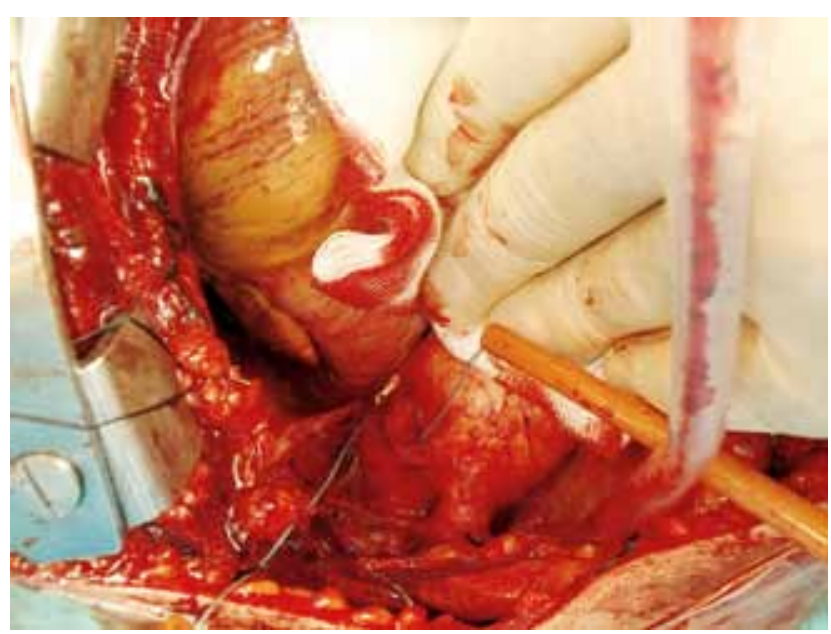

Fig. 1. Purse sutures for arch cannulation applied distally to the brachiocephalic artery
Either two-stage atrial or bicaval venous cannulation was performed. The distal part of the ascending aorta was freed from the adjacent tissues and pericardium, and an aortic cross-clamp was introduced proximally to the arterial cannulation site, partially clamping the innominate artery without occluding it. Myocardial protection was instituted with the induction of antegrade isothermic hyperkalemic blood cardioplegia with retrograde maintenance.

The ascending aorta was replaced in all cases. In 23 patients, only the supracoronary ascending aorta was replaced, whereas in 4 patients, the button modification of the Bentall procedure was conducted to replace the root and the ascending aorta.

Concomitant procedures included coronary artery bypass grafting in 5 patients, aortic valve replacement in 12 patients, mitral valve replacement in 3 patients, tricuspid annuloplasty in 4 patients, and left atrial radiofrequency ablation in one patient.

The data of the patients were collected retrospectively. Statistical analyses were performed using the SPSS software (SPSS Inc., Chicago, IL). Continuous variables were expressed as mean \pm standard deviation.

\section{Results}

The risk factors included hypertension in 7 patients, diabetes in 5 patients, smoking in 8 patients, chronic obstructive pulmonary disease in 6 patients, and reoperation in 2 patients. There were no deaths after the surgery. Neither permanent nor transient neurological events occurred during hospitalization.

There was no cannulation-related morbidity during the operation. Perioperative data of the patients are presented in Table I.

\section{Discussion}

There has been great progress in cardiac surgery since the introduction of cardiopulmonary bypass. Technical challenges about cannulation sites have mostly been overcome, but some may still occur in certain critical situations.

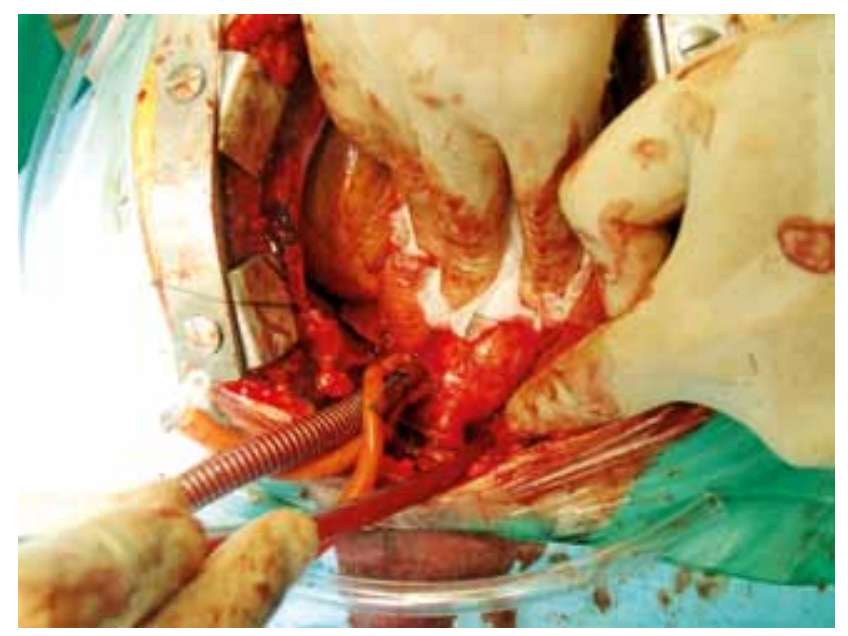

Fig. 2. Cannulated arch 
Tab. I. Perioperative data of the patients

\begin{tabular}{llcccc} 
& $N$ & Min & Max & Mean & Std. deviation \\
Age (years) & 27 & 53 & 75 & 64.0 & 7.2 \\
\hline Aortic diameter $(\mathrm{mm})$ & 27 & 45 & 63 & 54.9 & 5.5 \\
\hline Aortic cross-clamp time (min) & 27 & 27 & 110 & 62 & 25 \\
\hline Cardiopulmonary bypass time (min) & 27 & 38 & 143 & 84 & 37 \\
\hline Left ventricular ejection fraction (\%) & 27 & 32 & 65 & 51 & 9 \\
\hline Left ventricular end-systolic diameter (mm) & 27 & 29 & 55 & 41 & 7 \\
\hline Left ventricular end-diastolic diameter (mm) & 27 & 40 & 73 & 56 & 8 \\
\hline Postoperative bleeding (mL) & 27 & 150 & 1300 & 639 & 346 \\
\hline Intensive care unit follow-up (days) & 27 & 1 & 3 & 1.3 & 0.5 \\
\hline Postoperative hospitalization (days) & 27 & 5 & 8 & 6.4 & 0.9 \\
\hline
\end{tabular}

In order to avoid cerebral embolism, cardiac surgeons have started searching for new cannulation sites. Modifications of the standard cannulation and clamping techniques have been introduced to reduce the frequency of stroke related to atheromatous embolization [1]. Palpation of the aorta is much less sensitive and accurate than epiaortic ultrasound scanning in the selection of sites for cannulation, cross-clamping, etc. [4]. Intraoperative echography revealed irregular elevated lesions protruding into the aortic lumen from the intima in 13\% of ischemic heart disease patients. In order to prevent morbidity, arch cannulation and femoral artery cannulation can be employed for such patients $[5,6]$.

In the presence of an ascending aortic aneurysm, or when the aorta is unsuitable for cannulation, the femoral or iliac arteries are used for the procedure. Other indications for femoral artery cannulation include the lack of sufficient space in the ascending aorta, unstable patient condition requiring peripheral cannulation under local anesthesia, and the need for safe sternal reentry. Femoral cannulation may injure the cannulated vessel or lead to lymph fistulas, infection, embolization, and limb ischemia. It also completely occludes blood supply to the cannulated limb, which may result in ischemic complications. Retrograde arterial dissection may occur with an incidence of $0.2 \%$ to $1.3 \%$ [1]. In order to avoid some of these complications, axillary artery cannulation is recommended, especially for aortic dissections [7]. The ascending aorta itself may be cannulated in the presence of an aneurysm as well. In such cases, the patient's body temperature should be lowered, and a distal anastomosis should be established under hypothermia without clamping the aorta.

Cannulation of the distal aortic arch with the placement of the cannula tip beyond the cerebral vessels has been reported to result in significantly less cerebral emboli than ascending aorta cannulation. Therefore, distal aortic arch cannulation is concluded to be a useful technique for reducing cerebral emboli when the ascending aorta is found to be calcified during coronary artery bypass operations [8-9]. In a different study, femoral artery cannulation was discussed for its high mortality and morbidity in comparison to axillary artery cannulation. However, it was not retrograde embolization, but hypothermia that was believed to have been the cause of these complications [10]. In the present study, we focused on aneurysms of the ascending aorta. Although the brachiocephalic artery was partially clamped in order to replace the ascending aorta up to the aortic arch, we did not encounter any neurological events. The patients in our study group were carefully evaluated for the presence of aneurysms in the aortic arch and the distal ascending aorta. Patients with arch aneurysms were excluded from arch cannulation.

It was also postulated that femoral cannulation is associated with an increase of neurological events. One possible mechanism associated with this injury is retrograde perfusion from the femoral artery through a diseased aorta [7]. Other arterial cannulation sites may be of advantage in such situations. Aortic arch cannulation may be a good option, as it has the advantage of antegrade perfusion of the cerebral vessels without the risk of retrograde embolization.

In chronic diseases without proximal aortic dissection, femoral artery cannulation is suggested as a standard for arterial return due to the ease and speed of its performance. It was also reported not to increase the risk of neurological events. However, in patients requiring an operation of the ascending aorta without distal extension, the authors also suggested aortic arch cannulation with special consideration of the increased risk of injury [3]. The intrapericardial aorta is reported to be the best site, being the most resistant to tearing and dissection [1]. According to our observations, the aortic arch is thinner than the ascending aorta. Extreme caution must be taken in order not to damage the artery during cannulation, because cannulation site complications may prove disastrous. Moreover, the assistant should clearly expose the aortic arch for the surgeon to cannulate it.

Up until now, there have been no clinical studies solely concerned with aortic arch cannulation in ascending aortic 
aneurysms, which is the primary reason for the importance of our study. Although some authors have suggested cannulating the aortic arch, others had concerns about the feasibility of this procedure and its possible complications. According to our experience, acquired during the performance of the present study, the application of a cannula to the aortic arch is not overly complicated. The exposure of the arch is very easy, as is the introduction of the aortic cannula if assistance is provided. Although special cannulas for the cannulation of the aortic arch exist, we routinely used ascending aorta cannulas. The main difficulty may arise during decannulation. We routinely reduce the arterial systolic tension below $100 \mathrm{mmHg}$ during decannulation and tying. Pledgeted purse sutures are of critical importance for safe tying. In our opinion, aortic arch cannulation shortens the entire surgical procedure, as it does not require additional surgical sites. This also provides cosmetic benefits and helps prevent complications, such as surgical site infection.

The study is limited by its retrospective cross-sectional design, a small study population, and the lack of a control group.

In conclusion, aortic arch cannulation extending beyond the origin of the innominate artery may be a good option for patients with aneurysms limited to the ascending aorta.

\section{References}

1. Hessel EA, Hill AG. Chapter 5 - Circuitry and Cannulation Techniques. In: Gravlee GP, Davis RF, Stammers AH, Zngerleider RM (ed.). Cardiopulmonary Bypass: Principles and Practice. 3rd ed. Lippincott Williams \& Wilkins, Philadelphia 2008; 63-113.

2. Tuncer A, Yayla E, Polat A, Mataracı I, Keleş C, Aulasaleh S, Boyacıoğlu K, Kara I, Kaan K. Axillary artery cannulation in ascending aortic pathologies. Turk Gogus Kalp Dama 2011; 19: 539-544.

3. Lakew F, Pasek P, Zacher M, Diegeler A, Urbanski PP. Femoral versus aortic cannulation for surgery of chronic ascending aortic aneurysm. Ann Thorac Surg 2005; 80: 84-88.

4. Sylivris S, Calafiore P, Matalanis G, Rosalion A, Yuen HP, Buxton BF, Tonkin AM. The intraoperative assessment of ascending aortic atheroma: epiaortic imaging is superior to both transesophageal and direct palpation. J Cardiothorac Vasc Anesth 1997; 11: 704-707.

5. Bonatti J. Ascending aortic atherosclerosis - a complex and challenging problem for the cardiac surgeon. Heart Surg Forum 1999; 2: 125-135.

6. Hosaka S, Suzuki S, Kato J, Sasaki H, Fukuda N, Katahira S, Yoshii S, Kamiya K, Tada Y. Modification of the surgical strategy based on intraoperative echographic findings of atherosclerotic ascending aorta. Nihon Kyobu Geka Gakkai Zasshi 1997; 45: 1916-1921 [Abstract].

7. Sabik JF, Lytle BW, McCarthy PM, Cosgrove DM. Axillary artery: an alternative site of arterial cannulation for patients with extensive aortic and peripheral vascular disease. J Thorac Cardiovasc Surg 1995; 109: 885-891.

8. Borger MA, Feindel CM. Cerebral emboli during cardiopulmonary bypass: effect of perfusionist interventions and aortic cannulas. J Extra Corpor Technol 2002; 34: 29-33.

9. Borger MA, Taylor RL, Weisel RD, Kulkarni G, Benaroia M, Rao V, Cohen G, Fedorko L, Feindel CM. Decreased cerebral emboli during distal aortic arch cannulation: a randomized clinical trial. J Thorac Cardiovasc Surg 1999; 118: 740-745.

10. Polat A, Tuncer A, Tuncer EY, Mataracı I, Keleş C, Aulasaleh S, Boyacıoğlu K, Kara I. Is axillary arterial cannulation better than femoral arterial cannulation? Turk Gogus Kalp Dama 2012; 20: 186-193. 